\title{
Efficacy of two novel 2,2'-bifurans to inhibit methicillin-resistant Staphylococcus aureus infection in male mice in comparison to vancomycin
}

This article was published in the following Dove Press journal:

Drug Design, Development and Therapy

II October 2012

Number of times this article has been viewed

\author{
Wael M El-Sayed ${ }^{1,2}$ \\ Warda A Hussin ${ }^{3}$ \\ Mohamed A Ismail ${ }^{1,4}$ \\ 'Departments of Biological Sciences \\ and Chemistry, King Faisal University, \\ Al-Hofuf, Saudi Arabia; '2Department \\ of Zoology, University of Ain Shams, \\ Cairo, Egypt; ${ }^{3}$ Department of \\ Botany and Microbiology, Al-Azhr \\ University, Cairo, Egypt; ${ }^{4}$ Department \\ of Chemistry, Mansoura University, \\ Mansoura, Egypt
}

\begin{abstract}
The therapeutic efficacy of two novel bifurans and vancomycin in an animal model of a methicillin-resistant Staphylococcus aureus (MRSA) infection was compared. Adult male CF-1 mice (25-35 g) were intraperitoneally injected with $200 \mu \mathrm{L} /$ mouse containing $10^{7}$ cellforming units of MRSA. After 16 hours, animals were treated with $110 \mathrm{mg} / \mathrm{kg}$ of vancomycin, or $5 \mathrm{mg} / \mathrm{kg}$ of mononitrile bifuran (1A) or monocationic bifuran (1B) and killed after 8 hours. Treatment with bifurans did not cause any toxicity. Treatment of MRSA-infected animals with bifurans resulted in significant reductions in the viable bacterial count in blood, liver, kidney, and spleen. Colonies recovered from livers and kidneys of mice injected with $1 \mathrm{~A}$ or 1B lost the initial resistance pattern and became susceptible to methicillin and ciprofloxacin. MRSA elevated the serum urea level and activities of alanine aminotransferase and $\gamma$-glutamyl transpeptidase. MRSA also elevated the hepatic level of malondialdehyde, and serum levels of tumor necrosis factor and interleukin-6. MRSA also reduced the glutathione content and activities of catalase and glutathione $S$-transferase in liver. Similar to vancomycin, bifurans ameliorated most of the previous effects. Compound 1B was superior to 1A, and sometimes both provided better antistaphylococcal agents than vancomycin against MRSA pathogenesis. The present findings along with our previous studies support further evaluation of the efficacy of these bifurans in clinical studies.
\end{abstract}

Keywords: MRSA, bifuran derivatives, septicemia, glutathione system, antioxidants

\section{Introduction}

Sepsis caused by methicillin-resistant Staphylococcus aureus (MRSA) is a leading cause of severe diseases and mortality worldwide. Many organs are vulnerable to MRSA infections, including skin, kidney, and other organs, resulting in serious lifethreatening pathogenesis. ${ }^{1}$ Community- and nosocomial-acquired MRSA are common pathogens with resistance towards various classes of antibiotics, including methicillin, penicillin, and amoxicillin. ${ }^{2}$ Vancomycin has been the last choice for treatment of MRSA infection. However, in 2002 the emergence of vancomycin-resistant strains was reported in the USA. ${ }^{3}$ The list of effective antibiotics against MRSA is getting shorter over time, as accumulating mutations in $S$. aureus are building up, threatening possible widespread infection. It is evident that there is an escalating need for novel and efficient antistaphylococcal agents to control such invasive strains.

Biologically active amidines such as pentamidine and furamidine have long been used as antimicrobial agents. ${ }^{4,5} \mathrm{~A}$ series of ten novel bichalcophene derivatives were synthesized to achieve maximum antimicrobial activity, low toxicity, and better pharmacological properties. ${ }^{6}$ In our previous studies, these bichalcophenes
Correspondence: Wael M El-Sayed Department of Zoology, Faculty of Science, University of Ain Shams, Abbassia, Cairo II566, Egypt

Tel +2022482 I 633

Fax +20226842123

Emailwaelelhalawany@hotmail.com 
showed promising in vitro antibacterial activity against Gram-negative and Gram-positive bacteria, including S. aureus. Bichalcophenes also had synergistic activity, increasing the inhibitory effect of tetracycline against bacterial growth and elongating the postantibiotic effect, and were not toxic to murine cells. ${ }^{6}$

In the present study, the in vivo anti-MRSA activity of two selected bifurans from the bichalcophene series was investigated in adult male CF-1 mice. The efficacies of vancomycin and each of the tested bifurans on body and organ weight were compared in normal and MRSA infected animals. The effects of investigated bifurans on septicemia and on the bacterial count in kidney, spleen, and liver were determined. The MRSA infection poses an oxidative stress on cells through increasing tumor necrosis factor alpha (TNF- $\alpha$ ), which results in a reduction in the cellular antioxidant milieu. ${ }^{7}$ The effects of bifurans on TNF- $\alpha$, interleukin-6 (IL-6), and lipid peroxidation, kidney, and liver functions, and on antioxidant and drugmetabolizing enzymes were investigated in normal and MRSA-challenged mice.

\section{Materials and methods Chemicals}

All reagents were purchased from Sigma (St Louis, MO), except where indicated in the specified methods.

\section{Bacterial strains}

MRSA ATCC 33593 was purchased from the American Type Culture Collection (ATCC; Manassas, VA). The strain was susceptible to vancomycin and resistant to methicillin, ampicillin, and ciprofloxacin (Table 1). In all assays, inocula were prepared and diluted to contain $1.5 \times 10^{8}$ cell-forming units $(\mathrm{CFU}) / \mathrm{mL}$, which gave approximately $10^{7} \mathrm{CFU} / \mathrm{mouse}$ in a volume of $200 \mu \mathrm{L} .^{7}$

\section{Animal treatment and biological sample preparation}

Adult male CF-1 mice (25-35 g) were obtained from the Faculty of Veterinary Medicine, King Faisal University, and were maintained in a humidity- and temperaturecontrolled environment on a 12-hour light/dark cycle with continuous free access to food and water. The mice were divided into seven groups, with five mice each. The first group (naïve) was injected with isotonic saline. Groups two and three were intraperitoneally injected with a single dose of either mononitrile bifuran (Figure 1A) or monocationic bifuran (Figure 1B) at $5 \mathrm{mg} / \mathrm{kg}$ and killed after 8 hours.
Table I The resistance pattern of MRSA recovered from organs (post infection)

\begin{tabular}{|c|c|c|c|}
\hline \multirow{2}{*}{$\begin{array}{l}\text { Resistance pattern/ } \\
\text { treatments* }\end{array}$} & \multicolumn{3}{|c|}{ Body organ } \\
\hline & Liver & Kidney & $\overline{\text { Spleen }}$ \\
\hline \multicolumn{4}{|l|}{ Vancomycin/ } \\
\hline IA & $(I)^{-}$ & $(1)^{-}$ & $(1)^{-}$ \\
\hline IB & $(I)^{-}$ & $(1)^{-}$ & $(1)^{-}$ \\
\hline Vancomycin & $(I)^{-}$ & $(1)^{-}$ & $(1)^{-}$ \\
\hline \multicolumn{4}{|l|}{ Ciprofloxacin/ } \\
\hline IA & $(I)^{-}$ & $(1)^{-}$ & $(4)^{+}$ \\
\hline IB & $(I)^{-}$ & $(1)^{-}$ & $(I)^{-}$ \\
\hline Vancomycin & $(4)^{+}$ & $(4)^{+}$ & $(4)^{+}$ \\
\hline \multicolumn{4}{|l|}{ Methicillin/ } \\
\hline IA & $(4)^{-}$ & $(4)^{-}$ & $(16)^{+}$ \\
\hline IB & $(2)^{-}$ & $(4)^{-}$ & $(4)^{-}$ \\
\hline Vancomycin & $(16)^{+}$ & $(16)^{+}$ & $(16)^{+}$ \\
\hline \multicolumn{4}{|l|}{ Ampicillin/ } \\
\hline IA & $(0.25)^{-}$ & $(0.25)^{-}$ & $(4)^{+}$ \\
\hline IB & $(0.125)^{-}$ & $(0.25)^{-}$ & $(0.25)^{-}$ \\
\hline Vancomycin & $(4)^{+}$ & $(4)^{+}$ & $(4)^{+}$ \\
\hline
\end{tabular}

Groups 4-7 were injected with $200 \mu \mathrm{L} /$ mouse containing $10^{7}$ CFU of MRSA ATCC 33593 (MRSA). After 16 hours postinfection, groups 5-7 were injected intraperitoneally with either $110 \mathrm{mg} / \mathrm{kg}$ of vancomycin ${ }^{8}$ or bifurans $1 \mathrm{~A}$ or $1 \mathrm{~B}$ at $5 \mathrm{mg} / \mathrm{kg}$. After 8 hours posttreatment, all animals were sacrificed. Blood was collected and serum was immediately prepared, and the livers were quickly perfused in situ with ice-cold saline. The gallbladder was then carefully dissected away, and the remaining liver was homogenized in icecold buffer and subjected to centrifugation $(9000 \times \mathrm{g}$ for 15 minutes), and the supernatant was collected. Protein content of the supernatant and serum was determined using Folin-Ciocalteu phenol reagent (Sigma), as described by Lowry et al, ${ }^{9}$ and both were stored at $-80^{\circ} \mathrm{C}$ until assayed for enzyme activity. All animal procedures were approved by the King Faisal University Ethics and Animal Care Committee and were conducted in agreement with National Institutes of Health guidelines for the humane care of laboratory animals.
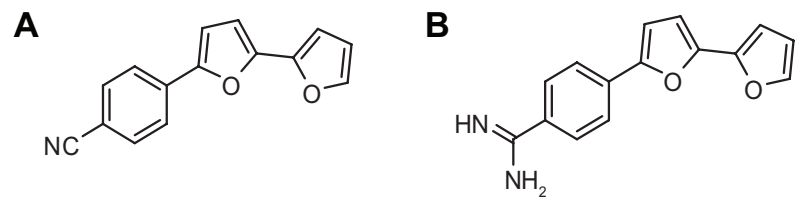

Figure I Bifuran derivatives as antibacterial agents; mononitrile bifuran (A) and monocationic bifuran (B). 


\section{Bacterial count}

A piece of liver, kidney, or spleen ( $200 \mathrm{mg}$ ) was homogenized in $2 \mathrm{~mL}$ of sterile isotonic phosphate buffer ( $\mathrm{pH}$ 7.2). The blood and the tissue filtrate were serially diluted and used immediately for bacterial count by spreading $100 \mu \mathrm{L}$ of serially diluted samples on Müller-Hinton agar supplemented with $\mathrm{NaCl}$ and left to grow for 24 hours at $37^{\circ} \mathrm{C}$ and the colonies were then counted and calculated as $\log _{10} \mathrm{CFU} / \mathrm{mL}$.

\section{Minimum inhibitory concentration measurement}

Antimicrobial susceptibility testing was performed using the broth microdilution method, following the recommendations of the Clinical and Laboratory Standards Institute (CLSI). Briefly, MRSA ATCC 33593 strain was cultured on Müller-Hinton agar medium and incubated for 24 hours at $37^{\circ} \mathrm{C}$ prior to susceptibility testing. An inoculum density was prepared in Müller-Hinton broth supplemented with $2 \% \mathrm{NaCl}$ and adjusted to match 0.5 MacFarland standard. A panel of different concentrations of each antibiotic was prepared in sterile 96-well microplates and inoculated with the test bacteria. Control samples were performed simultaneously by growing the bacteria without the tested antibiotic. The microtiter plates were incubated at $35^{\circ} \mathrm{C}$ for $16-20$ hours. The plates were subjected to reading at $600 \mathrm{~nm}$ using a plate reader, and susceptibility results were interpreted according to the CLSI. ${ }^{10}$

\section{Enzyme activity and biochemical analyses}

Serum alanine aminotransferase (sALT) activity was determined from the serum-dependent absorbance change of NADH oxidation at $340 \mathrm{~nm}$ in the presence of L-alanine, $\alpha$-ketoglutarate, and purified lactic dehydrogenase enzyme. ${ }^{11}$ The urea was hydrolyzed into ammonia and $\mathrm{CO}_{2}$ and the indophenol formed from the reaction of ammonia with hypochlorite and salicylate was measured. ${ }^{12}$ The $\gamma$-glutamyl transpeptidase ( $\gamma$-GT) activity was determined from the rate of formation of 5-amino-2-nitrobenzoate from L- $\gamma$-glutamyl3 -carboxy-4-nitroanilide in the presence of glycylglycine at $405 \mathrm{~nm} .{ }^{13} \mathrm{TNF}-\alpha$ and IL-6 levels in serum were measured using Bender MedSystems (Vienna, Austria) kits as described by the manufacturer. Malondialdehyde (MDA) was measured through estimation of a stable chromophore formed from the reaction of a chromogenic reagent, $\mathrm{N}$-methyl-2phenylindole, with MDA at $45^{\circ} \mathrm{C} .{ }^{14}$ Glutathione (GSH) peroxidase activity was determined from the azide-insensitive rate of oxidation of NADPH in the presence of hydrogen peroxide, GSH, and GSH reductase. ${ }^{15}$ GSH $S$-transferase
(GST) activity was determined from the conjugation of GSH with 1-chloro-2,4-dinitrobenzene detected by the change in absorbance at $340 \mathrm{~nm} .{ }^{16}$ Catalase activity was measured from the rate of dismutation of hydrogen peroxide to water and molecular oxygen in a two-step coupling reaction. ${ }^{17}$ Superoxide dismutase activity was measured in a coupling reaction through formation of formazan dye from tetrazolium salt by superoxide radicals generated by xanthine oxidase and hypoxanthine. ${ }^{18}$ GSH reductase activity was measured from the rate of reduction of oxidized GSH by NADPH. ${ }^{19}$ GSH reacts with 5,5'-dithiobis (2-nitrobenzoic acid), producing the disulfide form or oxidized GSH and 2-nitro-5-thiobenzoic acid (TNB). The rate of formation of TNB was monitored and GSH level was determined. ${ }^{20}$

\section{Statistical analysis of data}

Results are expressed as the means \pm standard error of mean. Treated-group size was five animals. Statistical analyses were performed using analysis of variance, followed by Fisher's protected least significant difference multiple-range test. The data were compared against those from the control animals. Differences were considered significant at $P<0.05$.

\section{Results}

On challenging mice with intraperitoneal injection of MRSA that was also resistant to ciprofloxacin and ampicillin, all animals developed bacteremia 24 hours postchallenge. The $\mathrm{LD}_{50}$ of bifurans investigated was $50 \mathrm{mg} / \mathrm{kg}$, at which 20 out of 40 mice developed severe toxicity and died within 24 hours. The injection of a single dose of these bifurans at $5 \mathrm{mg} / \mathrm{kg}$ resulted in a $100 \%$ survival rate in mice, and no toxicity signs appeared for 4 weeks postinjection. Intraperitoneal treatment of infected animals with a single dose of either vancomycin at $110 \mathrm{mg} / \mathrm{kg}$ or bifurans (1A or $1 \mathrm{~B}$ ) at $5 \mathrm{mg} / \mathrm{kg}$ for 8 hours resulted in significant reductions in the viable bacterial count in blood (Figure 2A). Bifurans were as efficacious as vancomycin in reducing the bacterial count $\left(\log _{10} \mathrm{CFU}\right)$ significantly in liver (Figure $2 \mathrm{~B}$ ), kidney (Figure 2C), and spleen (Figure 2D) as compared to infected untreated animals. The number of colonies recovered from these organs was higher than that recovered from blood, but the reduction percentage from control was almost the same. The morphology and microscopic examination of all colonies were identical to those of the inoculation strain. Selected colonies recovered from all organs of mice injected with vancomycin were allowed to grow overnight and showed the same resistance pattern as the strain used for injection of mice (Table 1). On the other hand, colonies recovered 

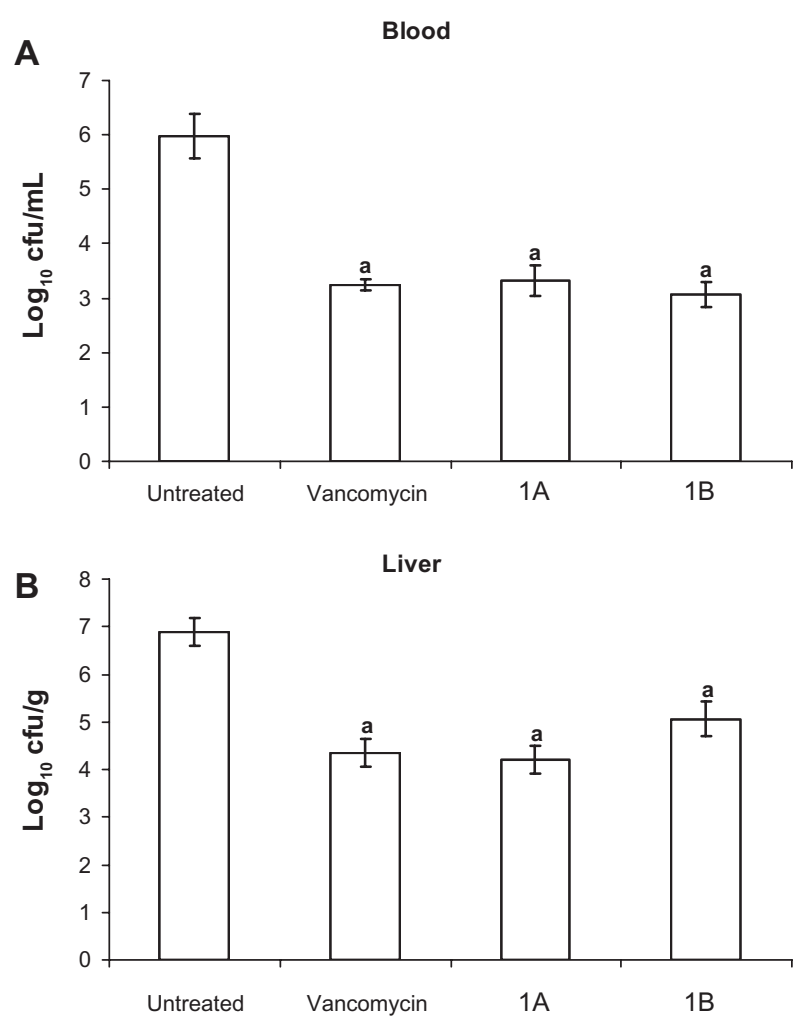

C Kidney

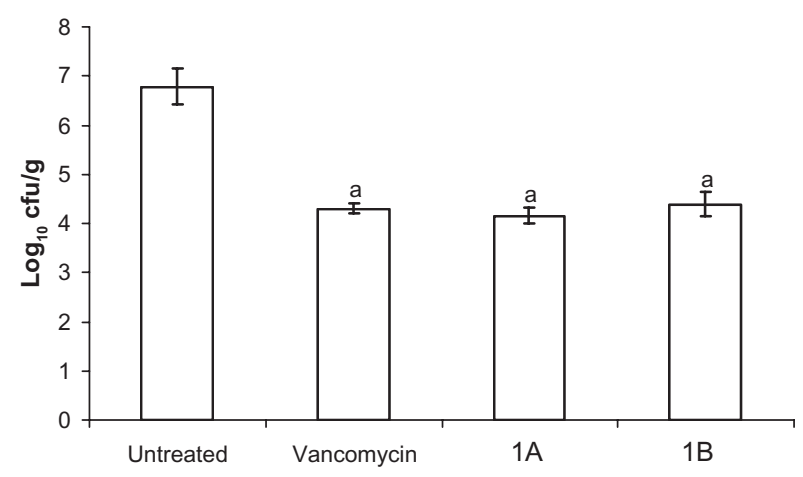

D Spleen

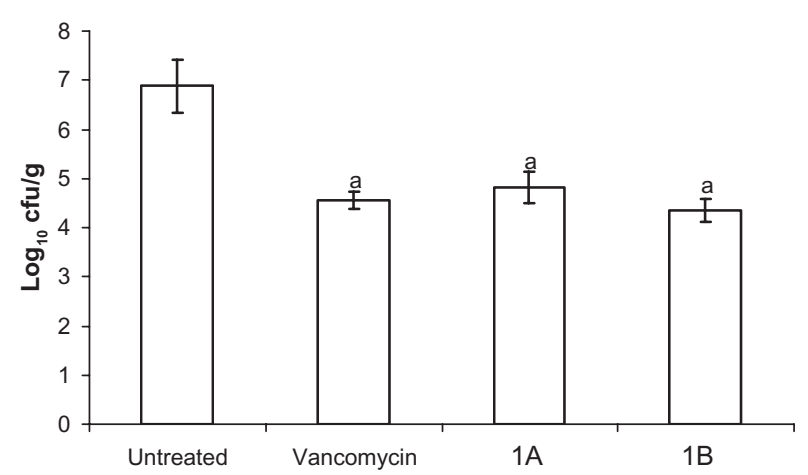

Figure 2 Viable bacterial count $\left(\log _{10} \mathrm{CFU} / \mathrm{mL}\right.$ blood or g tissue) in blood (A), liver (B), kidney (C), and spleen (D).

Notes: Data are expressed as means \pm standard error of mean, $n=5$. ${ }^{\text {Significant }}$ difference $(P<0.05)$ compared to untreated infected group. from livers and kidneys of mice injected with either bifuran investigated lost the initial resistance pattern and became susceptible to ampicillin, methicillin, or ciprofloxacin at $4 \mu \mathrm{g} / \mathrm{mL}$ and remained so after three passages (Table 1). However, colonies recovered from spleens of mice injected with $1 \mathrm{~A}$ did not lose the initial resistance pattern, while those isolated from spleens of mice treated with $1 \mathrm{~B}$ lost the initial resistance profile (Table 1).

Treatment with bifurans did not cause significant changes in body-weight gain nor in relative organ-weight percentage compared to control uninfected mice (Table 2). Injecting bacteria elevated the weight of all organs, but these elevations did not achieve statistical significance (Table 2).

None of the tested bifurans caused any change in the activity of serum alanine aminotransferase, indicating no hepatotoxicity at the dosing regimen used. MRSA infection caused a significant elevation in the activity of the enzyme in serum (Figure 3). Bifurans were as effective as vancomycin in reducing the serum activity of the enzyme compared to infected untreated animals. Similar findings were reported for $\gamma$-GT, another enzyme investigated as a marker of disorders in many organs. Bifurans were more efficacious than vancomycin in reducing the elevated activity of the enzyme (Figure 3). The MRSA infection significantly elevated the serum urea level in mice, but compounds $1 \mathrm{~A}$ and $1 \mathrm{~B}$ were able to restore normal levels (Table 3 ), while vancomycin did not affect the urea level in infected animals.

The bacterial infection elevated the hepatic MDA level (lipid peroxidation marker) as compared to control bacteriafree animals. Treating infected mice with vancomycin or bifurans significantly reduced the hepatic MDA level. Compound 1B was superior to the other bifuran investigated, and both were superior to vancomycin in reducing the

Table 2 Relative organ weight/body weight percentage in response to treatment of MRSA-infected mice with either novel bifurans or vancomycin

\begin{tabular}{|c|c|c|c|}
\hline \multirow[t]{2}{*}{ Treatment } & \multicolumn{3}{|c|}{ Relative organ weight \%* } \\
\hline & Liver & Kidneys & Spleen \\
\hline Control & $6.48 \pm 0.35$ & $1.34 \pm 0.04$ & $0.74 \pm 0.03$ \\
\hline IA & $6.26 \pm 0.31$ & $1.38 \pm 0.10$ & $0.89 \pm 0.19$ \\
\hline IB & $6.87 \pm 0.46$ & $1.27 \pm 0.04$ & $0.83 \pm 0.07$ \\
\hline Infected (MRSA) & $7.41 \pm 0.63$ & $1.44 \pm 0.14$ & $0.97 \pm 0.20$ \\
\hline Infected/Vancomycin & $5.93 \pm 0.4 I$ & $1.34 \pm 0.06$ & $0.83 \pm 0.15$ \\
\hline Infected/IA & $6.57 \pm 0.35$ & $1.25 \pm 0.06$ & $0.78 \pm 0.11$ \\
\hline Infected/IB & $5.89 \pm 0.23$ & $1.34 \pm 0.06$ & $0.73 \pm 0.05$ \\
\hline
\end{tabular}

Notes: *Mean \pm SEM, $n=5$. No significant changes were reported in the relative body weight nor in organ weight percentage. 


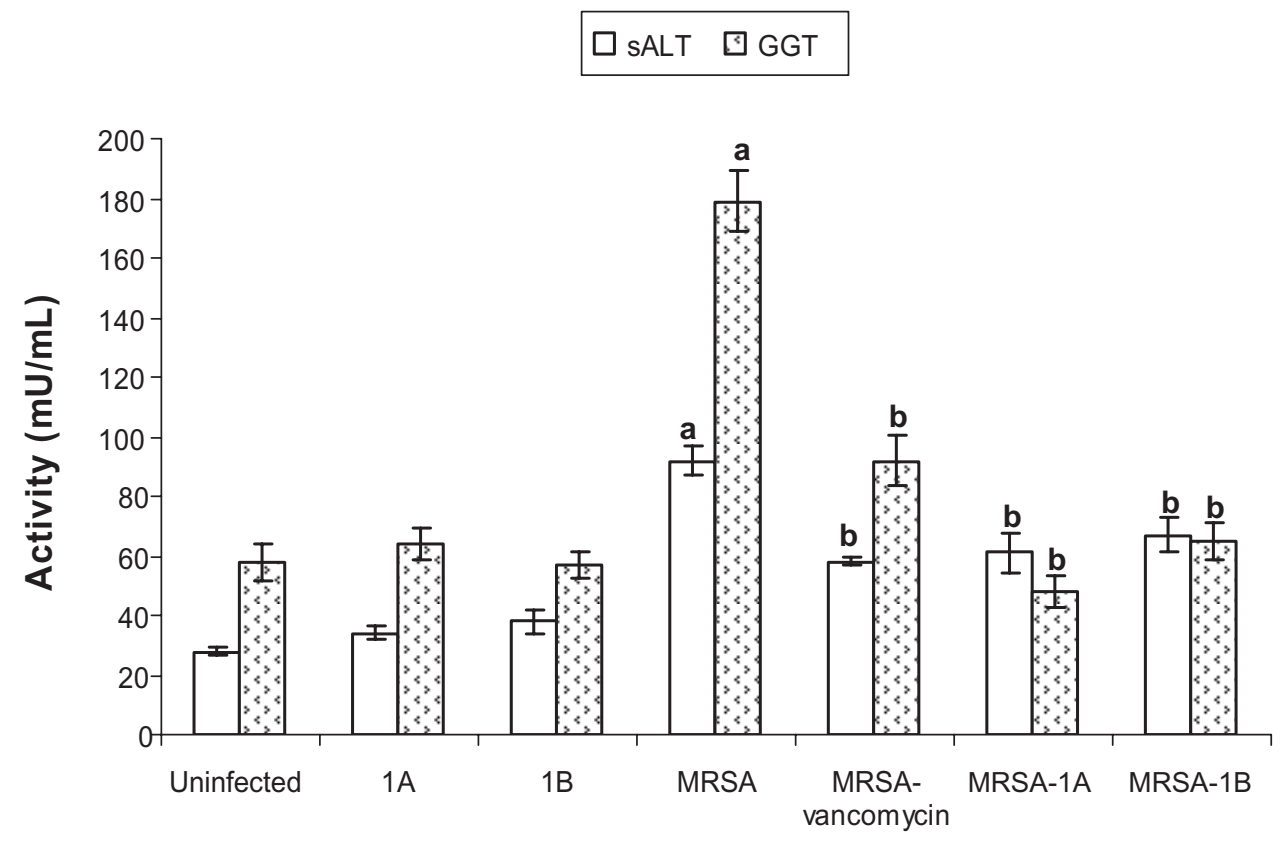

Figure 3 Effect of bifurans on serum activities $(\mathrm{mU} / \mathrm{mL})$ of alanine aminotransferase (sALT) and $\gamma$-glutamyl transpeptidase (GGT) in MRSA-infected animals. Notes: Data are expressed as means \pm standard error of mean, $n=5$. aSignificant difference $(P<0.05)$ compared to uninfected control group; ${ }^{b}$ significant difference $(P<0.05)$ compared to untreated infected group.

Abbreviation: MRSA, methicillin-resistant Staphylococcus aureus.

elevated MDA level compared to infected untreated animals (Table 3). Treating mice with compound 1A significantly elevated the reduced GSH level in liver in control animals. Bacterial infection significantly reduced hepatic GSH level compared to uninfected animals. Treating infected animals with either vancomycin $(P<0.05)$ or both bifurans $(P<0.001)$ significantly elevated the hepatic GSH content (Table 3) compared to infected untreated animals. The proinflammatory cytokines investigated (TNF- $\alpha$ and IL-6) were elevated in mice infected with resistant bacteria. Treating mice with either vancomycin or bifurans (1A or 1B) reduced both TNF- $\alpha$ and IL- 6 levels in serum compared to infected untreated mice (Figure 4).

Table 3 Effect of novel bifurans on reduced glutathione (GSH), malondialdehyde (MDA), and urea in MRSA-infected mice

\begin{tabular}{llll}
\hline Treatment & $\begin{array}{l}\text { GSH* } \\
\mu \mathrm{mol} / \mathbf{m g}\end{array}$ & $\begin{array}{l}\text { MDA* } \\
\mathbf{n m o l} / \mathbf{m g}\end{array}$ & $\begin{array}{l}\text { Urea* } \\
(\mathbf{m g} / \mathbf{d L})\end{array}$ \\
\hline Control & $4 I \pm 2 . I^{*}$ & $0.36 \pm 0.04$ & $30 \pm 3 . I^{\circ}$ \\
IA & $89 \pm 4.5^{\mathrm{a}}$ & $0.38 \pm 0.07$ & $29 \pm 3.3$ \\
IB & $46 \pm 3.9$ & $0.33 \pm 0.06$ & $35 \pm 2.3$ \\
Infected & $20 \pm 2 . I^{\mathrm{a}}$ & $1.87 \pm 0.2 \mathrm{I}^{\mathrm{a}}$ & $69 \pm 2.9^{\mathrm{a}}$ \\
Infected/vancomycin & $35 \pm 4.6^{\mathrm{b}}$ & $0.97 \pm 0.1 \mathrm{I}^{\mathrm{b}}$ & $68 \pm 3.2$ \\
Infected/IA & $68 \pm 6.7^{\mathrm{b}}$ & $0.77 \pm 0.08^{\mathrm{b}}$ & $46 \pm 2.9^{\mathrm{b}}$ \\
Infected/IB & $52 \pm 2.5^{\mathrm{b}}$ & $0.53 \pm 0.04^{\mathrm{b}}$ & $3 \mathrm{I} \pm 2.6^{\mathrm{b}}$ \\
\hline
\end{tabular}

Notes: andicates a significant difference $(P<0.05)$ from control; bindicates a significant difference $(P<0.05)$ from MRSA-infected group. *Mean \pm SEM, $n=5$.
Challenging animals with bacteria elevated GSH reductase (GR) and GSH peroxidase (GPx) activities in liver. Treating infected animals with vancomycin or any of the bifurans under study significantly reduced the activities of the enzymes to normal control levels (Figure 5). Treating uninfected mice with compound 1B elevated GPx activity compared to control mice. None of the treatments significantly affected superoxide dismutase activity in liver (Table 4). Bacterial infection in mice resulted in a significant reduction in catalase activity compared to control uninfected mice. With the exception of this reduction in catalase activity, none of the treatments significantly affected hepatic catalase activity (Table 4). Challenging mice with bacteria also resulted in a significant reduction in GST activity compared to control. On treating infected mice with vancomycin, enzyme activity was elevated compared to infected untreated animals. Treatment of infected mice with either bifuran investigated did not significantly affect the enzyme activity (Table 4).

\section{Discussion}

The rate of emergence of antibiotic-resistant $S$. aureus exceeds the rate of development of efficacious antistaphylococcal agents, posing a serious threat to public health and requiring a continuous effort for developing such agents. In the 


\section{TNF-a $\square \mathrm{IL}-6$}

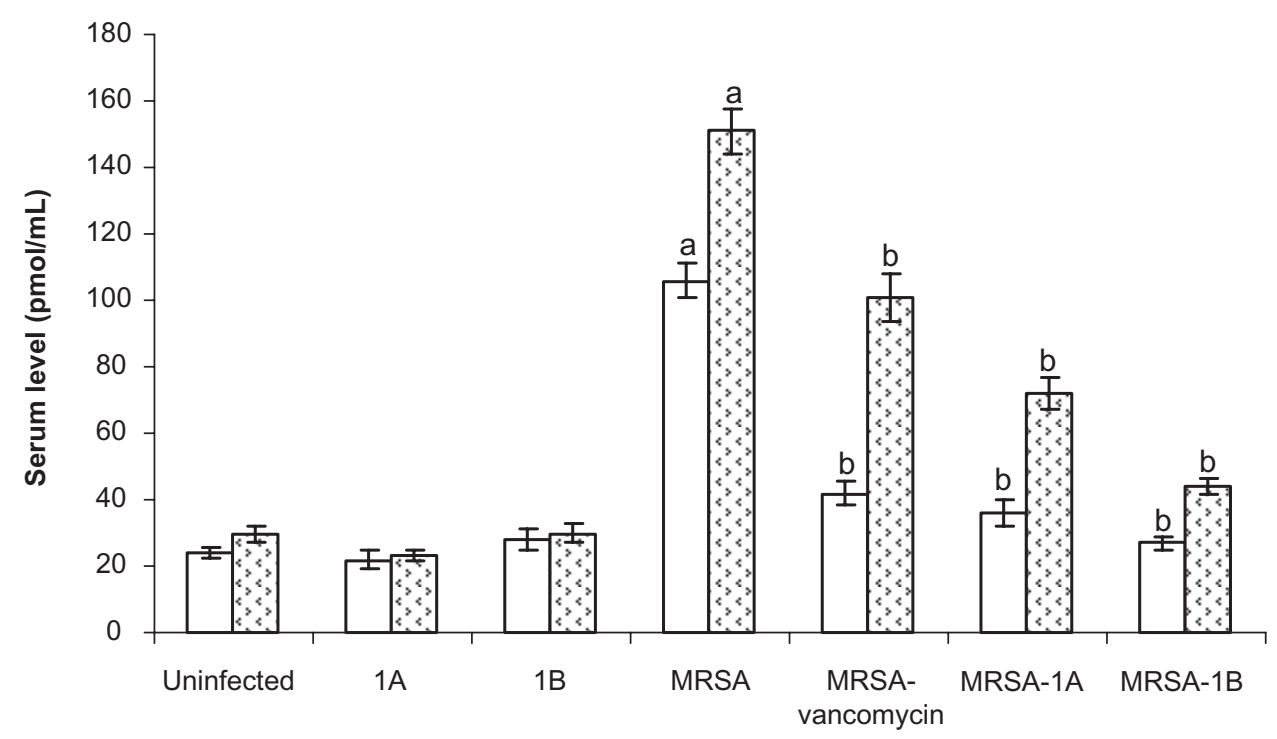

Figure 4 Effect of bifurans on serum levels (pmol/mL) of tumor necrosis factor alpha (TNF-a) and interleukin-6 (IL-6) in MRSA-infected animals. Notes: Data are expressed as means \pm standard error of mean, $n=5$. aSignificant difference $(P<0.05)$ compared to uninfected control group; ${ }^{b}$ significant difference $(P<0.05)$ compared to untreated infected group.

Abbreviation: MRSA, methicillin-resistant Staphylococcus aureus.

present study, two novel bifurans (1A and 1B) at a low dose of $5 \mathrm{mg} / \mathrm{kg}$ were injected into mice challenged with MRSA, and their effects were compared with vancomycin at $110 \mathrm{mg} / \mathrm{kg}$. In our previous study, these bifurans were shown to exert significant antibacterial activities against $S$. aureus with minimum inhibitory concentration values for both bifurans at $32 \mu \mathrm{M}$. Escherichia coli failed to develop resistance against these agents after $6-7$ days. ${ }^{6}$ In the present study, neither of the bifurans nor vancomycin at the dosing regimens used caused any toxicity to the animals, as indicated from the general appearance, body weight, organ weight, and the activity of sALT. MRSA infection caused insignificant

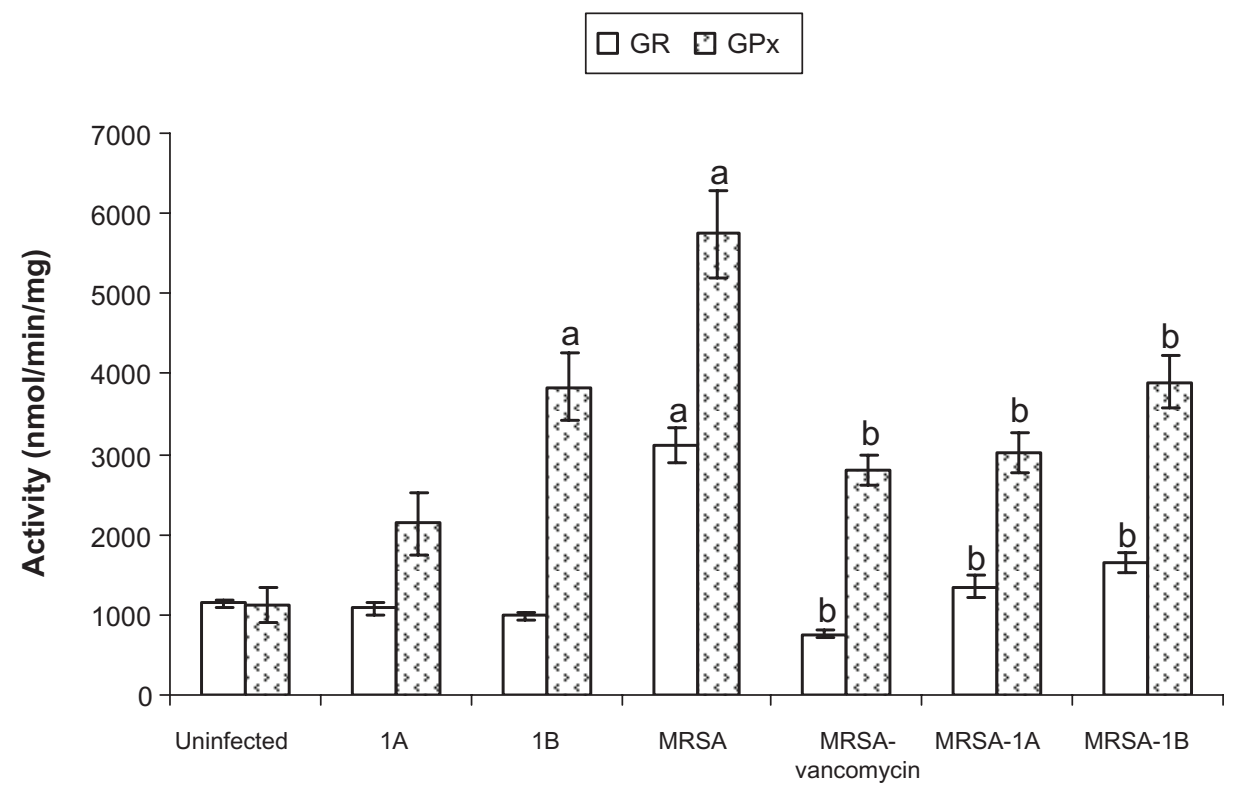

Figure 5 Effect of bifurans on hepatic activities (nmol/minute/mg) of glutathione reductase (GR) and glutathione peroxidase (GPx) in MRSA-infected animals.

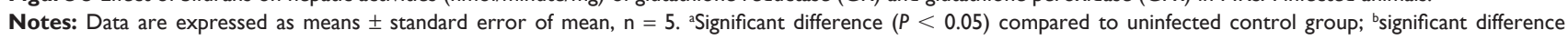
$(P<0.05)$ compared to untreated infected group.

Abbreviation: MRSA, methicillin-resistant Staphylococcus aureus. 
Table 4 Effect of novel bifurans on the activities of glutathione S-transferase (GST), superoxide dismutase (SOD), and catalase in MRSA-infected mice

\begin{tabular}{llll}
\hline Treatment & $\begin{array}{l}\text { GST activity* } \\
\text { (nmol/mg/min) }\end{array}$ & $\begin{array}{l}\text { SOD* } \\
\text { (mU/mg) }\end{array}$ & $\begin{array}{l}\text { Catalase* } \\
\text { (mU/mg) }\end{array}$ \\
\hline Control & $3109 \pm 363$ & $2.91 \pm 0.18$ & $576 \pm 59$ \\
IA & $2967 \pm 188$ & $3.01 \pm 0.32$ & $498 \pm 59$ \\
IB & $3533 \pm 205$ & $3.02 \pm 0.20$ & $539 \pm 25$ \\
Infected & $1982 \pm 114^{\mathrm{a}}$ & $3.24 \pm 0.33$ & $327 \pm 34^{\mathrm{a}}$ \\
Infected/vancomycin & $3117 \pm 353^{\mathrm{b}}$ & $3.19 \pm 0.21$ & $382 \pm 13$ \\
Infected/IA & $1953 \pm 148$ & $3.91 \pm 0.25$ & $361 \pm 23$ \\
Infected/IB & $2080 \pm 249$ & $3.09 \pm 0.36$ & $397 \pm 20$ \\
\hline
\end{tabular}

Notes: Indicates a significant difference $(P<0.05)$ from control; bindicates a significant difference $(P<0.05)$ from MRSA-infected group. *Mean \pm SEM, $n=5$.

elevations in relative organ weight (Table 2), which is in accordance with a previous report. ${ }^{7}$

Bifurans and vancomycin significantly reduced the bacteremia and organ infection in kidney, liver, and spleen (Figure 2A-D). The ability of bifurans to exert these effects after a single dose and for a short time reflects the high absorption rate into these organs. The short period of exposure to bifurans and MRSA in this animal model was selected to reduce interference from the host defense mechanisms. The used bifurans were able to resensitize MRSA to methicillin, ampicillin, and ciprofloxacin (Table 1), which may indicate the potential of such antistaphylocoocal compounds to abolish the expression of some resistance genes involved in cell-wall biosynthesis, reflecting the ability of these small molecules to overcome the cell-membrane barrier. ${ }^{21}$ In a previous study, a dicationic bifuran similar to $1 \mathrm{~B}$ was reported to bind specific human telomeric quadruplex in more than one groove. ${ }^{22}$

MRSA affects many organs through oxidative pathways, disturbing the cellular oxidant-antioxidant balance. ${ }^{3}$ MRSA resulted in significant elevations in TNF- $\alpha$ and IL-6 (Figure 4), which can lead to oxidative stress. ${ }^{23}$ This is in agreement with many previous reports. ${ }^{23-25}$ Elevations in cytokines such as IL-6 caused by MRSA enhance the pathogenesis of MRSA-associated diseases such as glomerulonephritis and nephritis. ${ }^{26,27}$ This may explain the elevations in serum urea level (Table 3 ) and the activity of $\gamma$-GT (Figure 3 ) caused by MRSA, which could be attributed to the inability of kidneys to dispose of urea and/or damage of the brush border. Bifurans ameliorated these elevations in urea level and $\gamma$-GT activity. One of the caveats of using vancomycin is the burden of nephrotoxicity it causes in about $17 \%$ of people, ${ }^{28,29}$ which is always marked by changes in serum urea level. In the current study, vancomycin did not ameliorate the elevation in urea level caused by MRSA. MRSA infection also resulted in significant reductions in the activities of hepatic GST and catalase (Table 4) and in the hepatic GSH content (Table 3). Similar findings were previously reported in spleen. ${ }^{3}$ Bifurans, similar to vancomycin, were able to ameliorate these effects, resulting in significant reductions in TNF- $\alpha$ and IL- 6 and elevations in hepatic GSH level, but only vancomycin was able to cause an elevation in GST activity in infected mice. This suggests that oxidative stress and free radicals produced by resistant $S$. aureus and the associated damage in cellular antioxidants play an important role in the pathogenesis of this bacterium. ${ }^{3}$ MRSA caused a significant elevation in hepatic MDA, indicating a high rate of lipid peroxidation, which is known to disturb the integrity of cellular membranes, leading to severe cell damage and loss of enzymes and activity.,24 The ability of bifurans and vancomycin to inhibit lipid peroxidation in liver can be arranged in the following order: 1B $>1 \mathrm{~A}>$ vancomycin (Table 3 ). A similar order was shown on measuring the antioxidant activity of bifurans: compound $1 \mathrm{~B}$ had an activity equivalent to $\sim 66 \%$ of vitamin $\mathrm{C}$ activity, while compound $1 \mathrm{~A}$ activity was equivalent to $\sim 34 \%$ at the investigated concentration range of $50-500 \mu \mathrm{M}$ (data not shown). In addition to the antioxidant effects, the change in resistance pattern in colonies recovered from liver, kidney, and spleen suggests a molecular change in the bacterial genome, but further investigation is required.

MRSA resulted in an elevation in hepatic GPx activity (Figure 5) and a reduction in catalase activity (Table 4), and both are responsible for scavenging and decomposition of hydrogen peroxide, but GPx is nonspecific and can scavenge other hydroperoxides. The elevations in GR and GPx activities (Figure 5) caused by MRSA could be a compensation mechanism. Both bifurans and vancomycin reduced the activities of GR and GPx elevated by MRSA. This is contradictory to what Chakraborty et al found in the spleens of Swiss mice, where they mentioned that vancomycin-resistant $S$. aureus reduced the activities of superoxide dismutase, GPx, and GR and vancomycin restored the activities of these enzymes. ${ }^{3}$ With the paucity of information in the literature about the effects of resistant $S$. aureus on cellular antioxidant status, this contradiction could be attributed to the difference in exposure period ( 10 days versus 24 hours) or the high dose of vancomycin they used $(500 \mathrm{mg} / \mathrm{kg} /$ day for 10 days versus a single dose of $110 \mathrm{mg} / \mathrm{kg}$ ).

\section{Conclusion}

The bactericidal activity of the investigated bifurans observed in vitro was confirmed in mice. The efficacy of bifurans at a dose of as low as $5 \mathrm{mg} / \mathrm{kg}$ was similar to that of vancomycin 
at a dose of $110 \mathrm{mg} / \mathrm{kg}$ in eradication of MRSA infection in a murine model. Although compound 1B (monocationic bifuran) was superior to compound 1A (mononitrile bifuran) in our previous in vitro studies, in the present study this structure-based differentiation was less evident. With the exception of elevation of GSH caused by $1 \mathrm{~A}$ and GPx activity caused by $1 \mathrm{~B}$ in healthy animals, both bifurans were very much similar. However, in a few instances, 1B was different from 1A. Only 1B resulted in loss of the initial resistance pattern of the MRSA recovered from spleen. In addition, $1 \mathrm{~B}$ was statistically better than $1 \mathrm{~A}$ in reducing the elevation in hepatic MDA and serum urea levels caused by MRSA infection, and neither bifuran caused any nephrotoxicity within the time limits of the experiment. Although further studies are needed for the pharmacokinetics and metabolism of these agents, a common metabolic pathway resulting in similar active metabolite(s) is possible. It was suggested that the cyano group in $1 \mathrm{~A}$ and amidine in $1 \mathrm{~B}$ could be converted into amide group through the action of cytochrome P450 3A $4 .{ }^{30}$ These findings, along with previous studies, support further evaluation of the efficacy of these bifurans in clinical studies.

\section{Acknowledgment}

This project was supported by King Faisal University, Deanship of Scientific Research, grant 130145.

\section{Disclosure}

The authors report no conflicts of interest in this work.

\section{References}

1. Kokai-Kun JF, Chanturiya T, Mond JJ. Lysostaphin as a treatment for systemic Staphylococcus aureus infection in a mouse model. J Antimicrob Chemother. 2007;60:1051-1059.

2. Cantoni L, Wenger A, Glauser MP, Bille J. Comparative efficacy of amoxicillin-clavulanate, cloxacillin, and vancomycin against methicillinsensitive and methicillin-resistant Staphylococcus aureus endocarditis in rats. J Infect Dis. 1989;159:989-993.

3. Chakraborty SP, Kar Mahapatra S, Sahu SK, et al. Internalization of Staphylococcus aureus in lymphocytes induces oxidative stress and DNA fragmentation: possible ameliorative role of nanoconjugated vancomycin. Oxid Med Cell Longev. 2011;2011:942123.

4. Ismail MA, Arafa RK, Brun R, et al. Synthesis, DNA affinity, and antiprotozoal activity of linear dications: terphenyl diamidines and analogues. J Med Chem. 2006;49:5324-5332.

5. Ward CP, Wong PE, Burchmore RJ, et al. Trypanocidal furamidine analogues: influence of pyridine nitrogens on trypanocidal activity, transport kinetics, and resistance patterns. Antimicrob Agents Chemother. 2011;55:2352-2361

6. Hussin WA, Ismail MA, El-Sayed WM. Biological evaluation of novel 4-substituted phenyl-2,2'-bichalcophenes and aza-analogues as antibacterial agents: structural activity relationship. Journal of Pharmacy and Pharmacology. Epub ahead of print.

7. Tsao SM, Hsu CC, Yin MC. Garlic extract and two diallyl sulphides inhibit methicillin-resistant Staphylococcus aureus infection in BALB/cA mice. J Antimicrob Chemother. 2003;52:974-980.
8. Hegde SS, Reyes N, Skinner R, Difuntorum S. Efficacy of telavancin in a murine model of pneumonia induced by methicillin-susceptible Staphylococcus aureus. J Antimicrob Chemother. 2008;61:169-172.

9. Lowry OH, Rosebrough NJ, Farr AL, Randall RJ. Protein measurement with the Folin phenol reagent. J Biol Chem. 1951;193:265-275.

10. Clinical and Laboratory Standards Institute. Methods for Dilution Antimicrobial Susceptibility Tests for Bacteria That Grow Aerobically: Approved Standard. 7th ed. Wayne: CLSI; 2006.

11. Wroblewski F, LaDue JS. Serum glutamic pyruvic transaminase in cardiac with hepatic disease. Proc Soc Exp Biol Med. 1956;91: 569-571.

12. Kaplan A. Urea. In: Kaplan LA, Pesce AJ, editors. Clinical Chemistry. The CV Mosby Co; St Louis, MO: 1984.

13. Persijn JP, van der Slik W. A new method for the determination of $\gamma$-glutamyltransferase in serum. J Clin Chem Clin Biochem. 1976;14: 421-427.

14. Esterbauer H, Schaur RJ, Zollner H. Chemistry and biochemistry of 4-hydroxynonenal, malondialdehyde and related aldehydes. Free Radic Biol Med. 1991;11:81-128.

15. Flore L, Gunzler WA. Assays of glutathione pereoxidase. Methods Enzymol. 1984;105:114-121.

16. Habig WH, Jakoby WB. Glutathione S-transferases (rat and human). Methods Enzymol. 1981;77:218-231.

17. Aebi H. Catalase in vitro. Methods Enzymol. 1984;105:121-126.

18. Malstrom B, Andreasson L, Reinhammaer B. Measurement of superoxide dismutase activity. In: Boyer P, editor. The Enzymes. New York: Academic Press; 1975.

19. Smith IK, Vierheller TL, Thorne CA. Assay of glutathione reductase in crude tissue homogenates using 5,5'-dithiobis(2-nitrobenzoic acid). Anal Biochem. 1988;175:408-413.

20. Ellman GL. Tissue sulfhydryl groups. Arch Biochem Biophys. 1959;82: $70-77$.

21. Bonde M, Højland DH, Kolmos HJ, Kallipolitis BH, Klitgaard JK. Thioridazine affects transcription of genes involved in cell wall biosynthesis in methicillin-resistant Staphylococcus aureus. FEMS Microbiol Lett. 2011;318:168-176.

22. White EW, Tanious F, Ismail MA, et al. Structure-specific recognition of quadruplex DNA by organic cations: influence of shape, substituents and charge. Biophys Chem. 2007;126:140-153.

23. Celine Lee SY, Seong IW, Kim JS, et al. Enhancement of cutaneous immune response to bacterial infection after low-level light therapy with $1072 \mathrm{~nm}$ infrared light: a preliminary study. Photochem Photobiol B. 2011;105:175-182.

24. Jung E, Perrone EE, Liang Z, et al. Cecal ligation and puncture followed by MRSA pneumonia increases mortality in mice and blunts production of local and systemic cytokines. Shock. 2012;37:85-94.

25. Watkins RL, Pallister KB, Voyich JM. The SaeR/S gene regulatory system induces a pro-inflammatory cytokine response during Staphylococcus aureus infection. PLoS One. 2011;6:e19939.

26. Kodama T, Santo T, Yokoyama T, et al. Postoperative enteritis caused by methicillin-resistant Staphylococcus aureus. Surg Today. 1997;27: 816-825.

27. Yoh K, Kobayashi M, Yamaguchi N, et al. Cytokines and $\mathrm{T}$ cell responses in superantigen-related glomerulonephritis following methicillin-resistant Staphylococcus aureus infection. Nephrol Dial Transplant. 2000;15:1170-1174.

28. Nishino Y, Takemura S, Minamiyama Y, et al. Targeting superoxide dismutase to renal proximal tubule cells attenuates vancomycin-induced nephrotoxicity in rats. Free Radic Res. 2003;37:373-379.

29. Dieterich C, Puey A, Lyn S, et al. Gene expression analysis reveals new possible mechanisms of vancomycin-induced nephrotoxicity and identifies gene markers candidates. Toxicol Sci. 2009;107: 258-269.

30. Zhang Z, Li Y, Stearns RA, Ortiz De Montellano PR, Baillie TA, Tang W. Cytochrome P450 3A4-mediated oxidative conversion of a cyano to an amide group in the metabolism of pinacidil. Biochemistry. 2002;41: 2712-2718. 
Drug Design, Development and Therapy

Dovepress

\section{Publish your work in this journal}

Drug Design, Development and Therapy is an international, peerreviewed open-access journal that spans the spectrum of drug design and development through to clinical applications. Clinical outcomes, patient safety, and programs for the development and effective, safe, and sustained use of medicines are a feature of the journal, which

has also been accepted for indexing on PubMed Central. The manuscript management system is completely online and includes a very quick and fair peer-review system, which is all easy to use. Visit $\mathrm{http}: / / \mathrm{www}$.dovepress.com/testimonials.php to read real quotes from published authors.

Submit your manuscript here: http://www.dovepress.com/drug-design-development-and-therapy-journal 